\title{
Association between Social Media Addiction and Depression of Students in Colleges of Education on the Copperbelt Province, Zambia
}

\author{
Harry Jordan Silomba ${ }^{*}$, Dr Akakandelwa Akakandelwa ${ }^{2}$, Professor Sophie Kasonde Ng'andu ${ }^{3}$ \\ ${ }^{1}$ Lecturer, Department of Education; Educational Psychology. Mufulira College of Education Zambia. \\ ${ }^{2}$ Senior lecturer, Department of Library and Information studies, University of Zambia. \\ ${ }^{3}$ Senior lecturer, Department of Psychology Sociology and Special Education, University of Zambia. \\ *Corresponding Author: Harry Silomba Jordan, Mufulira College of Education, Zambia
}

\begin{abstract}
This study investigated the association between social media addiction and depression among students in colleges of education on Zambia's Copperbelt Province. The study utilised the survey method to solicit data from a sample of five hundred and seventy-nine (579) college students who were drawn from three (3) public and three (3) private colleges of education on the Copperbelt. Bergen Social Media Addiction Scale (BSMAS) and Patient-Reported Outcomes Measurement Information System (PROMIS) questionnaires were employed for data collection. Subsequently, Pearson correlation coefficient was employed to determine the relationship between social media addiction and depression. The findings indicated that social media addiction negatively correlates with depression and depression significantly predicts social media addiction.
\end{abstract}

Keywords: Social Media; College Students; Depression; Copperbelt Zambia.

\section{INTRODUCTION}

Boyd \& Ellison (2007) define social media as web-based services that permit people to construct a public or semi-public profile within the social media system. It also articulates a list of other users with whom they share associations within the social media field. Dollarhide (2020) defines social media as computer-based innovations that encourage sharing of thoughts, contemplations, and data through the structure of virtual organisations and networks. Social media gives users access to electronic content, which incorporates personal information, documents, videos, and photos. Most individuals use social media to make and maintain friendships, to keep in touch with the extended family, to network career opportunities, to identify people with like interests, and share ideas, feelings, insight, and emotions, to access information and entertainment (Dollarhide 2020; Looy, 2016; Boyd \&Ellison, 2007). Users access social media platforms using various digital devices like the computer, tablet or smartphone.

Social media usage has become an indispensable and inseparable part of many individuals' daily lives (Boyd \& Ellison, 2007; Looy, 2016; Andreassen et al., 2017; Niranjjan et al., 2017), particularly among young adults. Of late, almost half of the world population (49\%; 3.80 billion) actively uses social media, and these figures are rapidly swelling every day (Kemp, 2020). Digital 2020 Zambia reports that there were 4.43 million Internet clients in Zambia in January 2020. The number of Internet users in Zambia expanded by 595 thousand (+16\%) between 2019 and 2020. Internet penetration in Zambia remained at $24 \%$ in January 2020. Subsequently, there were 2.30 million social media clients in Zambia in January 2020. The quantity of social media users in Zambia expanded by 360 thousand (+19\%) between April 2019 and January 2020 (Kemp, 2020). Social media penetration in Zambia stood at $13 \%$ in January 2020, and it has been reported to be on the increase among Zambians young adults (Akakandelwa \&Walubita, 2017; Kemp, 2020).

Depression is a significant mental health problem that constitutes a severe challenge in personal and public health worldwide (Hankin et al., 1998; WHO, 2020). Depression affects how a person feels, the way one thinks and acts. Common symptoms of depression include loss of pleasure in previously rewarding or enjoyable activities, having a pessimistic view of the future, feeling as though life is ruthless and troublesome. Symptoms also show sleeplessness (insomnia), tiredness, fatigue, feelings 
of guilt or low self-worth and low concentration in various activities (Hankin et al., 1998; WHO, 2017). The World Health Organization (WHO) report that more than 264 million people suffer from depression, and surprisingly, only a fraction receive treatment (de Choudhury, 2013; WHO, 2020). The impact of depression can be long-lasting or recurrent and can dramatically affect a person's ability to function and live a rewarding life. It can likewise influence a person's everyday schedule of exercises such as studying, working and family tasks. Furthermore, the extreme degree of sadness can prompt suicidal acts. WHO (2020) reports that approximately 800000 people commit suicide yearly. Suicide has been recognised as the subsequent driving reason for death among youngsters aged 15-29 years who are prone to excessive social media usage (Akakandelwa and Walubita, 2017).

Social media addiction is characterised as the excessive use of social media. Rahmatullah\&Zhao (2020) describe social media addition as excessive social media usage, driven by an uncontrollable urge to use social media, and commit so much time and exertion to social media, a situation that impair other essential life areas. Various studies advanced in the past decade have mainly explored the opportunities provided by social media (Baccarella et al., 2018). Recently, many scholars have begun to examine social media's adverse effects on its user, particularly in relation to depression. While various factors contribute to depression (Costello et al., 2008), evidence from a growing body of literature suggests that excessive social media usage leads individuals to various adverse health problems, including depression (Pantic et al., 2012; Cramer \& Inkster, 2017; Kircaburun, 2018; Baccarella et al., 2018; Bilgin\&Taş, 2018; İbrahim, 2019; Kalkan\& Bhat, 2020; Rahmatullah\& Zhao, 2020). However, very few studies of this nature have been undertaken in less developed countries like Zambia. Therefore, this study's primary objective was to investigate the correlation between social media addiction and depression among students in the Copperbelt Province of Zambia.

\section{STUdy OBJECTIVES}

This study's main objective was to investigate whether there was an association between social media addiction and depression among students in colleges of education on the Copperbelt Province of Zambia. The specific objectives of this study were to:

1. Determine the level to which college students are addicted to social media usage.

2. Determine the level of depression due to social media addiction among the students.

3. Establish the association between social media addiction and depression among students.

\subsection{Significant of the Study}

It is hoped that this study will contribute to the existing body of knowledge regarding students' use of social media and its associated effects on their depression. It is also expected that this study's findings will increase awareness of the adverse effects of excessive use of social. Besides, this study's results can be used to advocate for designing counselling programs to mitigate the adverse effects of excessive use of social media among students in colleges of education. Finally, it is anticipated that this study will stimulate further studies regarding social media and its impact on students' depression levels in tertiary learning institutions.

\section{RESEARCH METHODOLOGY}

This study adopted a descriptive survey research design. Six hundred respondents were randomly selected from six colleges of education on the Copperbelt Province of Zambia. Bergen Social Media Addiction Scale (BSMAS)was used to collect data on students' use of social media and to measure the extent to which students were addicted to social media (Andreassen et al., 2017). Subsequently, Patient-Reported Outcomes Measurement Information System (PROMIS) was a tool that provided self-report assessments of multiple mental, physical, and social domains and it offered researchers access to reliable, valid, and flexible measures of depression. The scale has been correlated and validated with other commonly used depression instruments, including the Center for Epidemiological Studies Depression Scale (CES-D), Beck Depression Inventory (BDI-II) and the Patient Health Questionnaire (PHQ-9) (Choi et al., 2014). Use of the PROMIS in this study seems significant because the scale aims to grade the severity of depression (Choi et al., 2014). Subsequently, the scale has of late proven its effectiveness in measuring depression by various researchers across the globe (Pilkonis et al., 2011; Lin et al., 2016; Shensa et al., 2018 Yan et al., 2020). Conversely, its measure 
has greater precision (less error) than most conventional measurements (NIH, 2018). PROMIS depression scale asked participants how much of the time in the previous seven days, they had encountered depression, including feeling hopeless, worthless, helpless, or depressed (Pilkonis et al., 2011). The data obtained were analysed using the Statistical Package for the Social Science, Version 23. The strength of the correlation between social media addiction and depression effects was measured based on Akoglu (2018) guidelines. Thus, precisely -1 revealed a perfect negative relationship, a correlation of -0.70 , showed a strong negative relationship between variables. Additionally, a correlation of -0.50 , revealed a moderate negative association, a correlation of -0.30 and -0.20 revealed a weak negative relationship while 0.0 indicated a no linear relationship.

\section{Results}

\subsection{Respondent's Demographic Characteristics}

Six hundred questionnaires were distributed; out of which 579 were returned, giving a response rate of $96.5 \%$. Table 1 presents the demographics of the respondents. Four hundred and thirty-four (74.9\%) of the respondents were from public colleges, and $145(25.1 \%)$ were from private colleges. Two hundred and ninety-two (50.4\%) of the total respondents were females, and $287(49.6 \%)$ were males. Ninety-two (15.9\%) were aged 19-20 years, 327 (56.5\%) were aged 21-25 years, and 160 (27.6\%) were aged above 26 years. The majority of the respondents $(73.7 \%)$ were single, while only $26.3 \%$ were married. One hundred and ninety-five $(33.7 \%)$ of the respondents were in their first year, $197(34.0 \%)$ were in their second year, and $187(32.3 \%)$ were in their third year.

Table1. Demographic Characteristics

\begin{tabular}{|l|l|l|l|}
\hline Variables & Values & Frequency (n=579) & Percentage \\
\hline \multirow{3}{*}{ College status } & Public & 434 & $74.9 \%$ \\
\cline { 2 - 4 } & Private & 145 & $25.1 \%$ \\
\hline \multirow{3}{*}{ Gender } & Male & 287 & $49.6 \%$ \\
\cline { 2 - 4 } & Female & 292 & $50.4 \%$ \\
\hline \multirow{3}{*}{ Age in years } & $19-20$ & 92 & $15.9 \%$ \\
\cline { 2 - 4 } & $21-25$ & 327 & $56.5 \%$ \\
\cline { 2 - 4 } & Above 26 & 160 & $27.6 \%$ \\
\hline \multirow{3}{*}{ Year of Study } & Married & 152 & $26.3 \%$ \\
\cline { 2 - 4 } & Single & 427 & $73.7 \%$ \\
\cline { 2 - 4 } & Year One & 195 & $33.7 \%$ \\
\cline { 2 - 4 } & Year Two & 197 & $34.0 \%$ \\
\cline { 2 - 4 } & Year Three & 187 & $32.3 \%$ \\
\hline
\end{tabular}

\subsection{Level of Social Media Usage Among College Students}

The level usage of social media among the student was measured using duration (time, months and the years) and frequency use. The results revealed that $35(6.0 \%)$ respondents had been actively using social media for less than six months; 131 (22.6\%) respondents for 6-12 months; 305 (53.4\%) respondents for 2-5 years; and $105(18.0 \%)$ respondents for more than five years (Figure 1).



Figure1. How long respondents have been actively using social media 
Association between Social Media Addiction and Depression of Students in Colleges of Education on the Copperbelt Province, Zambia

Table 3 below shows that $271(46.8 \%)$ respondents reported that they visited social media platforms several times in a day, $181(31.3 \%)$ respondents visited social media platforms once a day, $57(9.8 \%)$ visited social media platforms at least twice a week, 43 (7.4\%) visited social media platforms once a week, and $27(4.6 \%)$ respondents rarely visited social media platforms. Furthermore, $246(42.5 \%)$ respondents reported that they spent about 30-60 minutes on social media every day, 213 (36.9\%) respondents reported that they spent about 2-3 hours per day on social media, and $120(20.7 \%)$ respondents spent four or more hours on social media per day.

Table3. Level of Social Media usage

\begin{tabular}{|c|c|c|c|}
\hline Variables & Values & Frequency & Percentage \\
\hline \multirow{2}{*}{$\begin{array}{c}\text { Frequency of visits on } \\
\text { social media sites }\end{array}$} & Several times a day & 271 & 46.8 \\
\cline { 2 - 4 } & Once a day & 181 & 31.3 \\
\cline { 2 - 4 } & Twice a week & 57 & 9.8 \\
\cline { 2 - 4 } & Once a week & 43 & 7.4 \\
\cline { 2 - 4 } & Rarely & 27 & 4.6 \\
\hline Time spent on social \\
media
\end{tabular}

When asked to rate themselves regarding the levels to which they were using social media. Twentyfour $(4.1 \%)$ respondents rated themselves rare users; $85(14.7 \%)$ respondents rated themselves moderate users; $150(25.9 \%)$ respondents rated themselves heavy users; and 320 (55.3\%) respondents rated themselves very heavy users (Table 4).

Table4. Degree of social media use

\begin{tabular}{|l|l|l|}
\hline & Frequency & Percentage \\
\hline Rare user & 24 & 4.1 \\
\hline Moderate user & 85 & 14.7 \\
\hline Heavy user & 150 & 25.9 \\
\hline Very heavy user & 320 & 55.3 \\
\hline Total & 579 & 100.0 \\
\hline
\end{tabular}

\subsection{Level of Addiction to Social Media Among Students}

As earlier stated, social media addiction level was measured using BSMAS. The scale utilizes an eight (8) item Likert scale which was scored 1-5. The scores were totaled, the minimum score being 8 , and the maximum being 40. Thus, 1-15 was rated normal; 16-23 was rated mild; 24-31 was rated moderate; and 32-40 was rated high. The results revealed that $1.2 \%$ of the respondents were rated normal, $5.9 \%$ were rated mild, $35.6 \%$ were rated moderate, and $57.3 \%$ were rated high (Table 5).

Table5. Level of addiction among participants

\begin{tabular}{|l|l|l|}
\hline Addiction level & Frequency & Percentage \\
\hline Normal & 7 & 1.2 \\
\hline Mild & 34 & 5.9 \\
\hline Moderate & 206 & 35.6 \\
\hline High & 332 & 57.3 \\
\hline Total & 579 & 100.0 \\
\hline
\end{tabular}

\subsection{Level of Depression Among Students}

With the PROMIS depression scale aid, eight different questions were asked to investigate whether addiction to social media could trigger students' depression. The results are summarized in Figure 2 below. The study established that $79.7 \%$ of the respondents felt depressed when not logged on social media; $73.6 \%$ indicated that people's comments left them helpless and confused; $72.9 \%$ felt upset when trying to cut down time on social media; $71.3 \%$ reported that people's posts used to disturb them; $67.2 \%$ felt emotionally exhausted; $61.7 \%$ often lost interest in the activities they previously used to enjoy; $57.6 \%$ felt that life was meaningless or worthless; whereas $54.1 \%$ wanted to give up on everything. 
Association between Social Media Addiction and Depression of Students in Colleges of Education on the Copperbelt Province, Zambia



Figure2. Depression construct and SM use

Depression among respondents was determined using eight items which was scored 1-5 scale. These categories were spaced equally between the minimum and maximum points. Hence, the maximum score was 40 , while the minimum score was 8 . Thus, depression levels were further categorized as Very high (32-40), high (24-31), Moderate (16-23), and Low (15-22). The results are summarized in Table 6 and it reveal that $38.3 \%$ of the respondents scored very high, 36.4\% scored high, $18.5 \%$ scored moderate, and 6.7\% scored low depression levels. When very high and high are combined, the results show that $74.7 \%$ of the respondents experienced high levels of depression behaviour.

Table6. Table Degree of Depression

\begin{tabular}{|l|l|l|l|}
\hline & Frequency & Percent & Cumulative Percent \\
\hline Very High & 211 & 36.4 & 36.4 \\
\hline High & 222 & 38.3 & 74.8 \\
\hline Moderate & 107 & 18.5 & 93.3 \\
\hline Low & 39 & 6.7 & 100.0 \\
\hline Total & 579 & 100.0 & \\
\hline
\end{tabular}

\subsection{Association Between Social Media Addiction and Depression}

Pearson correlation test was conducted at alpha $=0.01$ to test the null hypothesis $(\mathrm{H} 0)$ : A correlation does exist between levels of social media addiction and students' depression. Results are presented in table 7 below. The results revealed that the level of addiction was negatively correlated with depression ( $\mathrm{rho}=-0.158, \mathrm{p}=0.001)$.

Table7. Hypothesis 2 Test Results correlations $(N=579)$

\begin{tabular}{|l|l|l|l|l|l|}
\hline $\begin{array}{l}\text { Health } \\
\text { conditions }\end{array}$ & Mean & SD & $\begin{array}{l}\text { Pearson } \\
\text { Correlation }\end{array}$ & P-Value & Comment \\
\hline $\begin{array}{l}\text { Degree of } \\
\text { Depression }\end{array}$ & 18.82 & 7.433 & $-.158^{* *}$ & 000 & $\begin{array}{l}\text { Negative } \\
\text { correlation; } \\
\text { Accept } \mathrm{H}_{1}\end{array}$ \\
\hline
\end{tabular}

\section{DISCUSSION}

Social media has changed the way college students interact as such; it portrays a trend which affects their depression levels. Yet, the perceived association has not been explored among Zambian college students. Thus, the current study strives to fill up this gap.

In this regard, the study brought out notable variation in social media usage compared to their past experiences, more importantly; students were spending more time on social media than before. The results coincide with prior studies that found almost similar trends (Akakandelwa \& Walubita, 2017; Shilip\&Arun-Kanti, 2019; Alnjadat et al., 2019; Nyagah et al., 2019). The proceeding observations indicate that students' acquisition of advanced phones with many advanced features drives them to spend more time on social media platforms than before. 
The results suggest that college students spend a significant portion of their daily lives on social media websites. This has resulted in high addiction levels of social media usage and higher depression levels among the students. These findings confirm previous studies (Idubor, 2015; Groth et al., 2017; Kalkan\& Bhat, 2020).

A correlation between students' addictive usage of social media and depression yielded a complicated relationship. In line with other prior studies (Shaw \& Gant, 2002; Elhai et al. 2016; Bilgin\&Taş, 2018; İbrahim, 2019), the results showed a negative correlation. The results have revealed a possible inhibiting of depression, the more a student engages in social media. Precious studies have observed that the more students stay away from addictive social media usage, the more they get depressed (Kurcaburun, 2018). From this viewpoint, students' time on social media might be related to subsequent depressive symptoms. This may imply that students' quest to stay longer hours on social media might save as a compensation approach. Students may turn to social media to make up for real or perceived depression problems. Therefore, it can be argued that students may be caught on two webs: to continue surfacing using the same social media platform heavily, which appear to provide refuge as they attempt to offset higher depression level or to abandon in an attempt to reduce usage heavily but end up getting depressed. Since social media is quite captive (Niranjjan et al., 2017), students may not stay longer on the minimal use level but end up opting again to continue using social media heavily. They are therefore caught up in a spiral web. These results taken together indicate the possibility that these processes could be cyclical in nature, and that excessive use of social media may result from a combination of some or all of these overriding factors. These results seem to suggest that social media is carrying both positive and negative effects (Andreassen et al., 2017; Niranjjan et al., 2017). As such, it is contended that social media is beneficial as it can minimize depression, where it enhances effective collaboration. On the other hand, it may be detrimental if excessive usage brings about depression and other psychological problems (Kircaburun, 2018; Rahmatullah\& Zhao, 2020).

\section{CONCLUSiOn AND RECOMMENDATIONS}

This study has established high usage levels of social media among college education students on the Copperbelt Province of Zambia, resulting in higher social media addiction. Furthermore, the study has established evidence of high levels of depression among the students resulting from social media. The results indicate a negative correlation between social media addiction and depression among the students. Therefore, this study recommends that college authorities establish awareness, guidance, and counselling programs to mitigate the adverse effects of excessive use of social media among students.

\section{ACKNOWLEDGEMENT}

This work emerged from a paper that was submitted to the University of Zambia (UNZA) School of Education in partial fulfillment for the honor of a Doctor of Philosophy in Education Psychology by the principal author. We greatly thank anonymous reviewers for their active contributions and suggestions.

\section{REFERENCES}

[1] Akoglu, H. (2018). User's guide to correlation coefficients. Turkish Journal of Emergency Medicine.18 91-93: Date accessed $1^{\text {st }}$ August, 2020 from https://doi.org/10.1016/j.tjem.2018.08.001

[2] Akakandelwa A. \& Walubita G. (2017). Students 'Social Media Use and its Perceived impact on their social life: A Case Study of the University of Zambia. The International Journal of multi- Disciplinary research. ISSN: 3471-7102. www.ijmdr.net.

[3] Alnjadat, R., Hmaidi, M. M., Samha T. E., Kilani M. M. \& H. A. M. (2019). Gender variations in social media usage and academic performance among the students of University of Sharjah Journal of Taibah University Medical Sciences. Date accessed 12 ${ }^{\text {th }}$ May 2020, from https://doi.org/10.1016/j.jtumed. 2019.05.002.

[4] Andreassen, C. S., Pallesen, S. \& Griffiths, M. D. (2017). The relationship between addictive use of social media, narcissism, and self-esteem: Findings from a large national survey.

[5] Addictive Behaviors. Journal homepage: doi:10.1016/j.addbeh.2016.03.006 www.elsevier.com/locate/ad dictbeh date accessed $30^{\text {th }}$ June 2019.

[6] Baccarella, Christian \& Wagner, Timm\&Kietzmann, Jan \& McCarthy, Ian. (2018). Social media? It's serious! Understanding the dark side of social media. European Management Journal. 36. 431-438. 10.1016/j.emj.2018.07.002. 
[7] Bilgin, O., \&Taş, İ. (2018). Effects of perceived social support and psychological resilience on social media addiction among university students. Universal Journal of Educational Research, 6(4), 751- 758.Doi: 10.13189/ujer.2018.060418. Date accessed 12th May, 2020.

[8] Boyd, D. M., \& Ellison, N. B. (2007). Social network sites: Definition, history, and scholarship.

[9] Journal of Computer-Mediated Communication, 13(1), 210-230. https://doi.org/10.1111/j.1083-6101 .2007.00393.x

[10] Choi SW, Schalet B, Cook KF \&Cella D. (2014) Establishing a common metric for depressive symptoms: linking the BDI-II, CES-D, and PHQ-9 to PROMIS depression. doi: 10.1037/a0035768. PMID: 24548149; PMCID: PMC5515387. Available from: http://www.ncbi.nlm.nih.gov/pubmed/24548149.

[11] Costello, DM, Swendsen, J. \& Rose, JS. (2008) Risk and protective factors associated with trajectories of depressed mood from adolescence to early adulthood. Journal of Consulting and Clinical Psychology 76: $173-183$.

[12] Cramer, S., \& Inkster, B. (2017).Social media and young people's mental health and wellbeing. (Report.) London, England: Royal Society for Public Health (UK) and Young Health Movement (UK).

[13] de Choudhury M, Gamon M, Scott C. \& Horvitz E. (2013). Predicting depression via social media. Proceedings of the Seventh International AAAI Conference on Weblogs and Social Media.

[14] Dollarhide, Maya E. (2020) Investopedia: social media facilitates sharing ideas and thoughts. 2 May2019. https://www.investopedia.com/terms/s/social-media.asp (accessed 30th December, 2020)

[15] Elhai, J. D., Levine, J. C., Dvorak, R. D., \& Hall, B. J. (2016). Fear of missing out, need for touch, anxiety and depression are related to problematic smartphone use. Computers in Human Behavior, 63, 509-516. doi:10.1016/j.chb. Retrieved $10^{\text {th }}$ October, 2019.

[16] Hankin BL, Abramson LY, Moffitt TE, Silva PA, McGee R \& Angell KE (1998). Development of depression from preadolescence to young adulthood: emerging gender differences in a 10 - year longitudinal study. J Abnorm Psychol, 107(1), 128-40.Doi: 10.1037//0021- 843x.107.1.128. PMID: 9505045. Available from: http://www.ncbi.nlm.nih.gov/pubmed/9505045.

[17] Groth, G., Longo, L. \& Martin, J. (2017). Social media and college student risk behaviors: A Mini-review. Addictive Behaviors, 65, 87-91. PMID: 27816044 DOI: 10.1016/j.addbeh.2016.10.003. Date accessed $15^{\text {th }}$ November, 2019.

[18] İbrahim Tas (2019). Association between Depression, Anxiety, Stress, Social Support, Resilience and Internet Addiction: A Structural Equation Modelling. Malaysian Online Journal of Educational Technology Date accessed 12th June, 2020 from http://dx.doi.org/10.17220/mojet.2019.03.001.

[19] Idubor I. (2015). Investigating Social Media Usage and Addiction Levels among Undergraduates in University of Ibadan, Nigeria British Journal of Education, Society \&Behavioural Science 7(4): 291-301, ISSN: 2278-0998; DOI: 10.9734/BJESBS/2015/15808.

[20] Kalkan, B. \& Bhat Suniti, C. (2020). Relationships of Problematic Internet Use, Online Gaming, and Online Gambling with Depression and Quality of Life Among College Students International Journal of Contemporary Educational Research Volume 7, Number 1, June 2020, 18-28 ISSN: 2148-3868. Date accessed 18th July, 2020.

[21] Kemp S. (2020). Global Statshot Report. Data accessed $28^{\text {th }}$ December, 2020 from https://wearesocial. com/blog/2020/07/digital-use-around-the-world-in-july-2020.

[22] Kemp S. (2020). Data report, Zambia. Date accessed $26^{\text {th }}$ December, 2020 from https://datareportal.com/ reports/digital-2020-Zambia.

[23] Kircaburun, K., Alhabash, S., Tosuntaş, Ş.B. \& Griffiths.K.D. (2018). Uses and Gratifications of Problematic Social Media Use Among University Students: a Simultaneous Examination of the Big Five of Personality Traits, Social Media Platforms, and Social Media Use Motives Int J Ment Health Addiction. https://doi.org/10.1007/s11469-018-9940-6 Date accessed 16 ${ }^{\text {th }}$ December, 2020.

[24] Lin LY, Sidani JE, Shensa A, Radovic A, Miller E, Colditz JB, Hoffman BL, Giles LM, Primack BA. (2016) Association between Social Media Use and Depression among U.S. Young Adults. Depress Anxiety. 2016 Apr;33(4):323-31. Date accessed 16 ${ }^{\text {th }}$ September, 2020 from doi: 10.1002/da.22466. PMID: 26783723; PMCID: PMC4853817.

[25] Looy Amy Van. (2016). Social Media Management Technologies and Strategies for Creating Business Value. Springer International Publishing Switzerland. ISSN 2192-4333 ISSN 2192-4341 (electronic) DOI 10.1007/978-3-319-21990-5.

[26] National Institutes of Health (2018). Patient-Reported Outcomes Measurement Information System (PROMIS). Retrieved from http://www.nihpromis.org/ Date accessed $16^{\text {th }}$ December, 2020.

[27] Niranjjan R., Anand Raj., Prasad T \&Manikandan(2017). 'Prevalence of Internet Addiction and Effects of Social Media Usage among a Private Medical College Students, Pondicherry', International Journal of health Internet. 
[28] Nyagah, W. V. \&Mutisya. S. S. (2019). Demographic Differences in Online Social Networking Addiction among Undergraduate University Students in Nairobi Kenya.African Journal of Clinical ISSN: 978-9966936-05-9: 2019 Vol. 02, Issue 02. School of Human \& Social Sciences. Date accessed $16^{\text {th }}$ December, 2020.

[29] Pantic, I. (2014).Online social networking and mental health.Cyberpsychology, Behavior, and Social Networking, X(X), 1-6.

[30] Pilkonis PA, Choi SW, Reise SP, Stover AM, Riley WT \&Cella D. (2011) PROMIS Cooperative Group. Item banks for measuring emotional distress from the Patient- Reported Outcomes Measurement Information System (PROMIS®): depression, anxiety, and anger. Assessment. 18(3):263-83. doi: 10.1177/1073191111411667.PMID: 21697139; PMCID: PMC3153635.

[31] Rahmatullah, H. \& Zhao S. (2020). The relationship between social media addiction and depression: a quantitative study among university students in Khost, Afghanistan, International Journal of Adolescence and Youth, 25:1, 780-786. Accessed 15 ${ }^{\text {th }}$ May, 2020, from DOI: 10.1080/02673843.2020.1741407.

[32] Shaw, L. H., \& Gant, L. M. (2002). In defense of the internet: The relationship between internet communication and depression, loneliness, self-esteem, and perceived social support.

[33] Cyberpsychology and Behavior, 5(2), 157-171. Retrieved date 23rd November, 2019 from https://doi. org/10.1089/109493102753770552

[34] Shensa, A., Sidani, J. E., Dew, M. A., Escobar-Viera, C. G., \&Primack, B. A. (2018). Social Media Use and Depression and Anxiety Symptoms: A Cluster Analysis. American journal of health behavior, 42(2), 116-128. https://doi.org/10.5993/AJHB.42.2.11.

[35] Shilpi, R.S. \&Arun, K.G. (2019).Impact of Social Media Use of University Students. Journal of Statistics and Applications, 9(1): 36-43. DOI: 10.5923/j.statistics.20190901.05

[36] Yan, Y., Rychlik, K.L., Rosenman, M.B. et al. (2020) Use of PROMIS® to screen for depression in children with arthritis. PediatrRheumatol 18, 92 (2020). https://doi.org/10.1186/s12969-020-00482-. Date accessed $27^{\text {th }}$ Novermber, 2020.

[37] WHO, (2020) Fact Sheet on Depression retrieved 26 ${ }^{\text {th }}$ December 2020 from https://www.who.int/newsroom/fact-sheets/detail/depression.

[38] WHO. (2017). Depression and other common mental disorders global health estimates. World Health Organization. Accessed on $12^{\text {th }}$ May, 2020 from https://apps.who.int/iris/bitstream/handle/10665/2 54610/WHO-MSD-MER-2017.2.

\section{AUTHORS' BIOGRAPHY}

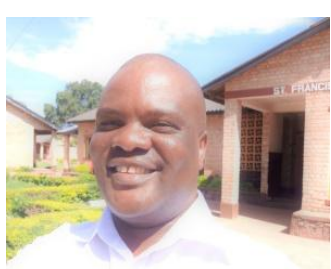

Zambia.
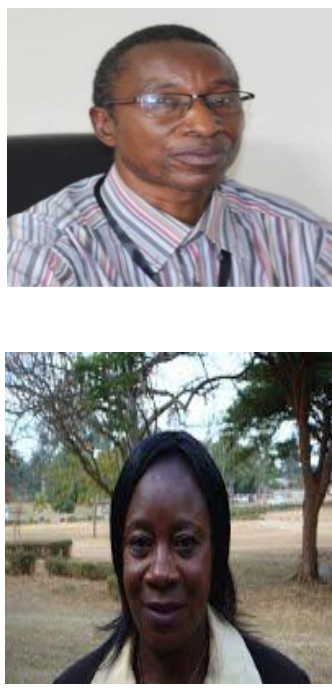

Harry Jordan Silomba, is a $\mathrm{PhD}$. Student undertaking a course in Educational Psychology. He joined the Ministry of Education as the primary school teacher in 2000. Currently, he holds a primary school certificate, a certificate in Special Education, advanced diploma in Educational Psychology, diploma and a Degree in Special Education as well as a Master's Degree in Educational Psychology from University of Zambia (UNZA). He is currently a full-time lecturer at Mufulira College of Education on the Copperbelt province,

Dr Akakandelwa, is a Senior Lecturer UNZA School of Education and Coordinator of its Master of Library and Information Science Program. He has previously held various posts at UNZA Library. He also served as a Senior Lecturer at Evelyn Hone College. Dr Akakandelwa currently holds a PhD from the University of Antwep in Belgium, a MLIS from the University of Botswana, and a BALIS from UNZA.

Prof. Sophie Kasonde-Ng'andu, an Associate Professor, obtainedher first degree in 1976 fromUNZA in Educational Psychology. She additionally got a Master's in Educational Psychology and Measurement at the Teachers College in New York. She further did a joint PhD program at Leiden and UNZA. From that point forwardshe has contributed broadly in instructive brain research, custom curriculum, and comprehensive training, among others. She has made an enormous commitment to the turn of events and development of a custom curriculum at Policy and Practices in Zambia. She has served UNZA in 
Association between Social Media Addiction and Depression of Students in Colleges of Education on the Copperbelt Province, Zambia

various portfolios as Assistant Dean Postgraduate and Head of Department.

Citation: Harry Jordan Silomba, et.al. "Association between Social Media Addiction and Depression of Students in Colleges of Education on the Copperbelt Province, Zambia" International Journal of Humanities Social Sciences and Education (IJHSSE), vol 8, no. 2, 2021, pp. 157-165. doi: https://doi.org/10.20431/2349. 0381.0802015 .

Copyright: () 2021 Authors. This is an open-access article distributed under the terms of the Creative Commons Attribution License, which permits unrestricted use, distribution, and reproduction in any medium, provided the original author and source are credited. 